\title{
Research on Inheritance and Development Trend of Chinese National Folk Dance
}

\author{
Liu Hui \\ School of Music, Shanxi Normal University, Xi'an, Shaanxi, China, 710000 \\ hunter2011@foxmail.com
}

Keywords: Inheritance and development trend, National folk dance, Chinese culture.

\begin{abstract}
As an important carrier of national culture, Chinese folk dance gets much attention and affirmation in social circles. This paper expounds the concept of folk dance, points out the ways and laws of the national folk dance inheritance, and then analyzes its development trend based on current situation in order to provide some references for the relevant researchers.
\end{abstract}

\section{Concept of National Folk Dance}

Dance is a kind of cultural phenomenon, is also an art form which conveys emotion via person's body action, look, expression, manner and costume. It is gradually formed the body and to reflect the values of a society to form. Folk dance refers to a nation or region in the development of material civilization and spiritual civilization, the work of the masses directly created by the masses, but also in the masses, but still in the form of dance. Folk dance is a nation in the process of historical development and people themselves created in the masses of the inheritance of dance forms. It reflects the people's life and traditional activities, with ethnic characteristics and regional style, can with the development of society and add new connotation and denotation. China is a multi-ethnic country. Each nationality has its own national characteristics of folk dance. These forms of folk dance show the unique form of the nation, which has accumulated the cultural phenomenon of the national spirit, aesthetic taste, customs and habits of the nation. Moreover, the formation of the nation, migration, living environment, economic foundation, social structure and other aspects are reflected. Folk dance itself has a strong national color and regional characteristics, is an important part of the national regional culture. Different cultural backgrounds gave birth to different forms of dance, creating different styles of dance culture.

\section{Models of Inheritance of National Folk Dance}

Inheritance in Family Communicatio. China is a civilization country with a long history. It not only has the convergence of the whole culture, but also has the unique national culture, showing a mixed style. As different culture, customs and habits of different nation create different styles of dance, the dance art has its own characteristics. For example, the Yi nationality has the Mei Qi asked, "Miao people have" Lusheng dance, "Tibetan have" Guo zhuang dance, Manchu "Taiping drum dance" and so on, Chinese ethnic dance together for Chinese culture to create a beautiful, colorful scenery. People of all ethnic groups through the dance of different attitude, dress and habits and the nation's other people or with other ethnic groups communicate to the nation's national culture to be in more profound level transmission down. But most people are dancing through the national heritage of future generations. Such as Yi "Mei Qi asked" dance, take it is family heritage. The mother daughter, elders through oral transmission to offspring tells the meaning of dance movements and essentials and hands-on teaching. From generation to generation, the dance of the now remains a very traditional original flavor of the dance style, so as to better inheritance of the nation about marriage custom culture.

Inheritance in Particular Occasions. The development of national folk dance is inseparable from the specific environment of brewing. Folk dance culture is in a specific environment and atmosphere in survival and development. A nation through the learning experience of the folk dance characteristics and style, to in-depth understanding of a certain culture understanding inherited. 
Such as: Yi compatriots reside in the mountains, rely on the survival of the mountains. History and the outside contact less, forming a semi closed living environment. This in a relatively closed geographical environment gave birth to the local Yi people honest, kind, hard-working character, and the river of Mei Qi asked "dance is the embodiment of the quality, it dancing pace and rhythm of the display of their life style. The people of all ethnic groups in China, in case of holidays, or weddings and funerals, etc., usually with the mood but the rise of dance, through dance to infect others, foil atmosphere. At the same time, in the national aesthetic psychology and social function of the drive, the common dance can make the dance to the development of collective creation. Through the national folk dance, this art form of communication, to achieve the rich and heritage of different national culture.

Inheritance in Continuous Evolution. With the continuous development of the social environment, folk dance also changes a lot. National culture in the various cultural matters has been inherited and developed. Now, continuously improve the degree of attention on the national folk dance, the state higher education through training a group of professional dancers. The dance professionals from the theoretical height of national folk dances were the norm. The national character of Chinese ethnic and folk dance is more pronounced. After the Third Plenary Session of eleven, through the investigation of several generations of the whole folk dancers buried, let the dance to appear on the stage. Qinglong County has become a regional identity card. At present, under the background of cultural development and prosperity, dance as a project of the national culture into the campus to be passed, at the same time, Qinglong County each year organizes the Kemeiqituo dance contest and so on. Via these good social environment activities, we protect the national folk music.

\section{Inheritance Laws of Chinese National Folk Dance}

Before China's reform and opening up, the development and heritage of minority folk dance ahas been seriously hampered. In a period of time, people will of minority folk dance as feudal superstition, think this is to entertain the farmers, and will eventually become extinct. Along with the continuous deepening of reform and opening to the outside world, minority folk dance has been the impact of foreign culture, many minority folk dance facing successors awkward. For example, cigarette case dance of the $\mathrm{Yi}$, due to the impact of foreign culture, resulting in the dance failed to get good inheritance and development, the dance appears the problem of single style and lack of connotation, once on the verge of extinction. Although the government has gradually strengthened the protection of minority folk dance. But there are many artists in the dance world. The artists themselves have little knowledge of the folk dance of the minority, but also very few go to the folk, the understanding of the folk dance is only from various types of performances and Art Festival. The artists themselves are not comprehensive to the folk dance of the minority nationality, it is impossible to carry on the national folk dance very well. But also by the eagerness of "dance" of the new concept and ideological influence, less part of artists to create works of folk dance shows the state is not foreign soil, minority folk dance to bring the new crisis. Of course, in addition to a small number of artists, more artists are willing to truly spread minority traditional culture, to carry out a variety of Minority Folk Dance Festival, and effectively promote the dissemination and heritage of ethnic minorities, but also promote the development of minority dance culture. This part effectively improves the visibility of Yunnan folk dance, and even the national folk dance spread to foreign countries. But we should treat this phenomenon in a dialectical way. Ethnology and cultural communication from the point of view, this is out of the local and the national dance communication, to achieve the exchange. In the development of the commodity culture and tourism, this kind of compound minority folk dance occupies most of the market share. From the perspective of historical and scientific national culture transmission, this kind of complex dance has damaged the long-term interests of the excellent traditional culture of minority nationality. With the continuous development of Yunnan Province tourism, minority folk dance has also been a good development, but many scholars also worry that, this kind of out the spread of commercial purposes may lead to ethnic and folk dance of vulgarization and superficial. In fact, such as a tower of ivory 
for the dimension from the draw force people often first of the dance interlude people table many people the sowing phenomenon does exist, this is the social transformation of the inevitable phenomenon.

\section{Development Trend of Chinese National Folk Dance}

Trend of Realism. As people do not understand the culture of the minority for a long time, people gradually formed a fixed thinking. It is generally believed that the folk dance is a tool to express emotions, and cannot truly reflect a profound theme. Folk dance has a very strong entertainment, but this is not a conflict with the theme of profound significance, such as dance, "his wife" is both entertaining and ideological, give people left a deep impression, many details are intriguing. In the future development of minority folk dance, to achieve better development, will present the characteristics of real. Modern concept of choreography is applied to the folk dance creation in the national folk dance to seek a better development, is bound to change the traditional thinking of creation, make full use of modern choreography ideas, breaking the traditional, ethnic and folk dance from the structure, composition and style innovation. To ensure that the original ecological folk dance based on into modern choreography element and the esthetic idea, break the traditional uniform dance ideas and realize the innovation of folk dance so as to create more time charm of folk dances of Chinese ethnic groups.

Trend of Combination. The classical folk dance worksfully embodies the characteristics of the original ecology of minority folk dance.Based on the integration of various ethnic characteristics of the equipment, costumes, it shows the people's daily life scenes. The original intention of the creation of the dance is entertainment and cultural heritage, which embodies the respect for the ancestors and the gods. This shows that the classical folk dance works, with rich cultural connotations. However, with the development of social economy, people's life style has changed greatly. Many customs and customs have gradually merged with the times. It can be seen that the development trend of minority folk dance is bound to develop in the direction of classical dance and modern dance. Yi traditional dance of the bell file dance ", for example, is classic in the traditional dances of the $\mathrm{Yi}$, dance after years of development has from the original single funeral dance development into the performance the dance of traditional scenes of life and positive content, simple style. This shift is attributed to the Yi People's intelligent wisdom, also cannot do without the recreation of modern art of it. On the stage of modern performance, the dance of the bell and the modern dance and the modern dance are the characteristics of the multi-symbiosis.

Trend of Diversification. The so-called diversification development mainly refers to the local, the world. The development of minority folk dance must be based on the Chinese traditional culture, in the national culture, which has a strong inclusive container, continuous innovation of national folk dance, dissemination and inheritance of outstanding folk traditional culture. Of course, based on the local basis, but also for the world development, to promote and spread the outstanding Chinese folk dance, let more people understand the traditional culture of our country. China's national folk dance is not only an important cultural heritage, but also a common cultural heritage of the world. From this perspective, the dissemination and inheritance of folk dance, but also to better promote the development of the world's cultural diversity.

\section{Conclusion}

The inheritance and protection of minority culture is of great significance to promote national harmony and strengthen national cohesion. Folk dance is an important part of minority culture, and it is an important task to strengthen the dissemination and inheritance of minority folk dance culture. Folk dance originated from life, is an important part of national culture, its development is influenced by many aspects of national culture. It is a rich display of national culture and national folk dance, which has been developed for various factors. In short, China's five thousand years of splendid culture in this shining pearl, it has its own development law. it is the people of China's cultural property, one of the most important parts. We should inherit and develop and evolve along 
own development law. We should explore the development of folk dance, the protection of the traditional folk dance culture heritage, edit a system of folk dance teaching materials, and create more popular works to promote the development of Chinese national folk dance culture.

\section{References}

[1] X.Y. Sun, On the Back ground of Chinese National Folk Dances, Journal of Shang qiu Teachers College, 2(2008)126-129.

[2] L. Zhu, Research on Dance Education at Primary and Secondary School and Inheritance of National Folk Dance, Northeast Normal University, 2011.

[3] H. Liang, The Research in the Application of Chinese National Folk Dance an Element in Preschool Education, D., Northeast Normal University, 2011.

[4] Z.P. Zhang, A Comprehension of the Inheritance, Innovation and Development of the National Folk Dance, J., Journal of Guzhou University, 20(2006)64-68. 